\title{
SOSYAL SERMAYE KAVRAMINA TÜRKIYE'DEKI ÖRGÜTSEL DAVRANIŞ ÇALIŞMALARI AÇISINDAN BİR BAKIŞ
}

Atıf/C: Yiyit, Tuba (2017). Sosyal Sermaye Kavramına Türkiye'deki Örgütsel Davranış Çalışmaları Açısından Bir Bakış. Hitit Üniversitesi Sosyal Bilimler Enstitüsü Dergisi, Yıl 10, Sayı 2, Aralık 2017, ss.1499-1520

Özet: Klasik yönetim yaklaşımından sonra ortaya çıkan yaklaşımlar sırasıyla insan, sistemler ve diş çevre gibi unsurları yönetim çalışmalar içine sokmuştur. Günümüzde ise örgütsel davranış disiplininin mikro konulara yoğunlaştığı, diğer yönetim çalışmalarının ise genelde örgütün çevresi ile olan ilişkisini betimleyecek kavramsal çerçeveler sunduğu görülmektedir. Bu noktada örgütsel davranış çalışmalarında etkili olan toplumsal güven, sosyal ilişkiler ve normlar gibi kavramlar temel alan sosyal sermaye önemli bir konu halini almaktadir. Sosyal sermayenin örgütsel davranışın ilgi alanında yer alan mikro değişkenlerle olan bağlantısının yeterince anlaşılamadiğını göstermektedir. Bu nedenle çalışmada sosyal sermayenin sahip olunan ağlar, sosyal ilişkiler, güven, sosyal normlar gibi makro unsurlarının, Türkiye'de mikro boyutta kalan örgütsel davranış çalışmalarında kullanım sıklığ incelenerek; alana ne tür katkı sağlayabileceğinin tartışılması amaçlanmiştır.

Anahtar Kelimeler: Sosyal Sermaye, Örgütsel Davranış

\section{An Overview of the Social Capital Concept With Regard To Organizational Behavioral Studies in Turkey}

Citation/(C: Yiyit, Tuba (2017). An Overview of the Social Capital Concept With Regard To Organizational Behavioral Studies in Turkey, Hitit University Journal of Social Sciences Institute, Year 10, Issue 2, December 2017, pp.1499-1520

Abstract: The approaches that emerged after the classical management theories, have introduced elements such as people, systems and the external environment into management studies. It is seen that the discipline of organizational behavior concentrates on micro issues while other management studies provide conceptual frameworks to describe the relationship between the organization and the environment. At this point social capital which is based on concepts such as social trust, social relationships and norms has an important role for organizational behavior studies. It is seen that micro variables that are interest of organizational behavior and social capital is not understood sufficiently. With this purpose we examine the frequency of use of macro elements such as social networks, social relations, trust and social norms in organizational behavior studies in Turkey and aimed to discuss what kind of contribution can contribute to the field.

Keywords: Social Capital, Organizational Behavior 


\section{I.GİRIŞ}

19.yy. sonu itibariyle örgütlerin makine olduğuna dair görüşler yıkılmaya başlamış, örgüt içerisinde insanın varlığının önemi anlaşılarak insan ilişkileri yaklaşımı ile birlikte örgütsel davranışın temelleri atılmıştır. İnsan ilişkileri yaklaşımı örgütün etkin ve verimli çalışmasında, insan ve insanlar arasındaki ilişkinin önemi üzerinde durmuş, insan kavramını işletmecilik uygulamalarına yansıtmıştır. İnsan ilişkileri yaklaşımı örgütsel davranış alanının temellerinin atıldığı, yönetim çalışmaları için kırılma noktası yaratan, odak noktası olarak verimlilik ve etkinlik kavramlarının yanında insanı temel alan bir dönemdir. Kendisinden sonra gelen sistem yaklaşımı ve koşul bağımlılık yaklaşımlarının baskın olduğu dönemde ise bireyin örgüt için önemi devam etmekle birlikte örgüt çalışmalarında çevreye olan vurgu da artmıştır. $\mathrm{Bu}$ dönemsel ayrım aslında yönetim çalışmalarında mikro ve makro çalışmalarının ayrımın da yoğunlaştığı dönemi oluşturmaktadır. Örgütsel davranış disiplini kendisini mikro konulara yoğunlaştırmış, diğer yönetim çalışmaları ise örgüt içi konulara eğilim göstermeyerek, genelde örgütün çevresi ile olan ilişkisini betimleyecek kavramsal çerçeveler sunmuştur. Gelinen noktada örgütsel davranışta ele alınan konular halen örgüt kültürü, örgütsel güven, örgütsel adalet, işgören mutluluğu, motivasyon, iş doyumu gibi örgüt boyutunda ele alınarak, insan ilişkileri yaklaşımı döneminde olduğu gibi, örgüt içi unsurlara yöneldiği görülmektedir. Mikro boyutta yapılan çalışmalar insanlar arası ilişkileri, kurumlar arası ilişkileri ve bu ilişkileri doğrudan etkileyen toplumsal güven, sosyal ilişkiler ve normlar gibi kavramları temel alan sosyal sermayenin önemini göz ardı edebilmektedir.

Sosyal sermaye 1900'lerin başında ortaya çıkan bir kavramken, 90'lı yıllara gelindikçe önemi daha fazla anlaşılmıştır. Bourdieu (1986), Coleman (1988), Putnam (2000) ve Fukuyama (1999)'nın çalışmaları ile önemi daha çok anlaşılan sosyal sermaye kavramı temelde bireyin sahip olduğu ağlar, sosyal ilişkiler, güven, sosyal normlar gibi insan ve grupların olduğu her yerde ortaya çıkan unsurları temel almaktadır. Ekonomik ve sosyal gelişme ve kalkınmayı doğrudan etkileyen bu kavramın işsizlik, istihdam, bireysel motivasyon, güven gibi kavramlarda belirleyici olması bakımından örgütsel davranış çalışmalarında da belirleyici bir unsur olarak yer alabilmektedir. Sosyal sermaye olgusunun sadece makro boyutta ele alınıyor olması, örgütsel davranışın ilgi alanında yer alan mikro değişkenlerle olan bağlantısının yeterince anlaşılamamasına neden olmaktadır. Bağlama özgü durumların 
keşfedilmesi için makro boyuttaki sosyal dinamikler ile örgüt dünyasının içinde olanlar arasında bağ kurmak gereklidir.

Bu sebeple çalışmada sosyal sermayenin sahip olunan ağlar, sosyal ilişkiler, güven, sosyal normlar gibi makro unsurlarının, Türkiye'de mikro boyutta kalan örgütsel davranış çalışmalarında kullanım sıklığı incelenerek; alana ne tür katkı sağlayabileceğinin tartışılması amaçlanmıştır.

\section{KAVRAMSAL ÇERÇEVE}

Sosyal sermaye kavramı sosyal bilimlerin pek çok alanında inceleme konusu olarak ele alınan ve toplumsal yapının anlaşılmasında kullanılan önemli bir kavramdır. Sosyoloji, iktisat, eğitim ve siyaset bilimcilerce incelen bu kavramın yaşamı, ekonomik ve sosyal kalkınma, eğitimde etkinlik, demokrasi ve yönetim, toplumsal (kolektif) eylemler, çalışma hayatı ve örgütleme gibi konularda araştırma konusu olmaktadır.

Kavramın tanımlanmasında temel alınan pek çok araştırmacı bulunmaktadır. $\mathrm{Bu}$ araştırmacılardan ilki olan Bourdieu (1986), sosyal sermayeyi sosyal ilişkiler ve bu ilişkilerin gücü ile kaynaklara ulaşabilme derecesinden yola çıkarak incelemiştir. Bu bakış açısına göre sosyal sermaye sosyal yükümlülük ve ilişkilerden oluşmakta, belirli koşullarda ekonomik sermayeye çevrilebilen ve kendini sınıfsal unvanlarla gösteren bir sermaye çeşididir (Tuncay, 2016). Sosyal sermayeye diğer bir bakış açısı da sosyal sermayenin ekonomik sermayeye dönüşmesi açısından ele alan Bourdieu'nun tersine, sosyal sermayenin insan sermayesine dönüşmesine yoğunlaşan Coleman tarafından yapılmıştır. Coleman (1988), sosyal sermayeyi beklentiler, yükümlülükler ve güvenilirlik açısından ele alarak, sosyal yapı içindeki bireylerin eylemlerini kolaylaştıran bir varlık olarak tanımlamıştır. Putnam (2000), ise sosyal sermayeyi, karşılıklı yarar için koordinasyon ve işbirliğini kolaylaştıran ağlar, normlar ve sosyal güven gibi örgütlerin sahip olduğu sosyal özellikler şeklinde ifade etmektedir. Fukuyama (1999), sosyal sermayeyi iki ya da daha fazla kişi arasında işbirliğini teşvik eden, resmi olmayan normlar; grup ya da örgütlerde ortak amaç için çalışma yeteneği olarak tanımlamaktadır (Özdemir, 2008).

Tanımlardan anlaşılacağı üzere bilim adamlarının sosyal sermayeye bakış açıları farklılaşmaktadır. Bourdieu, Coleman ve Putnam tanımlamalarında daha çok grup dayanışması ve yeniden yapılanma üzerinde durmaktadır. Lin, Burt ve Marsden gibi yazına katkı sağlayan diğer yazarlar ise sosyal sermaye tanımlarında sosyal ağlar içerisindeki kaynakların yerleşiklik ve ulaşılabilirliği 
üzerinde durmaktadırlar (Lin, 1999). Buradan sosyal ağlar, karşılıklı tanınma ve onaya yapılan yatırımın da sosyal sermaye tanımlarında geçen ve farklılaşan kısımları arasında yer aldığı çıkartılmaktadır.

Tanımlarda temel alınan bu noktaların karşılıklı ilişki içerisinde olduğunu söylemek mümkündür. Kısaca ifade etmek gerekirse insan, grup ve örgütler arasındaki ilişkiler ve ağlar, bu ilişkilerin oluşturduğu sosyal norm ve değerlerin ve gerek ilişkilerin gerekse norm ve değerlerin oluşturduğu güven unsurunu sosyal sermaye kavraminı etkileyen unsurlar arasinda saymak mümkün olmaktadır. Bu ilişkiler yapısal ve normatif olarak iki boyutta da açıklanabilmektedir. Yapısal açıdan ifade edilen kısım sosyal ilişkilerle oluşan ağları, normatif boyut ise güven ve karşıl1klılığa dayalı normlarla gelişen ağları ifade etmektedir (Stimson vd., 2003). Bir diğer yaklaşım ise formel ve informel ilişkiler olarak açıklanmaktadır. Burada informel ilişkiler kişilerin aile, eşler, arkadaşlar ve komşuları ile olan ilişkilerini ifade ederken; formel ilişkiler ise iş hayatındaki, toplumsal gruplar ve devletle kurulan ilişkileri içermektedir.

Bu durum bize sosyal sermayenin üç farklı boyutunu sunmaktadır. İlk boyut insanın bireysel olarak ilişkilerinden çok grup, örgüt gibi sosyal sistemlerin bir bütün olarak ele alındığı yapısal boyuttur (Kapu, 2008). Bu boyut kişiler arasındaki bağlantı kalıplarını, iletişim ağının yapısını, bu ilişkilerin varlığı ve yokluğu, elde edilecek bilgilerin ne derece bireysel ve kültürel değerlere bağlı olduğu ağa dâhil olabilme ve hiyerarşi gibi bileşenleri bulunmaktadır (Göksel vd., 2010). Yapısal boyutta daha çok birey, grup/örgüt arasındaki ilişkilerin yap1sal durumuna yer verilmiş oluğu görülmektedir. Ancak sosyal sermaye örgüt içerisindeki sosyal ilişkileri etkileyerek sosyal etkileşim bağlarında etkili olabilmekte ve hiyerarşi, iş ve karar akışlarını belirleyerek, sosyal ilişkilerin doğmasını sağlamaktadır (Turan, 2013: 54).

İkinci boyut ise insanların başkaları ile ilişkilerinden doğan ve davranışlarını etkileyen ve sayg1, arkadaşlik gibi durumlardan etkilenen ve sosyallik, benimsenme, prestij gibi sosyal ve bireysel motivasyonlar üzerinde duran ilişkisel boyuttur. $\mathrm{Bu}$ boyut duygusallığa dayalı güveni, normları ve zorunlulukları içermektedir. Duygusallı̆ga dayalı güven, güvenirlilik derecesi ve karş11ıklı bağımlılık, güven ilişkisi, ödül beklemeksizin yardımlaşma ve fedakâr davranışlar ile kendini gösterirken; takım çalışmasını destekleme, eleştiriye karşı hoşgörülü olma ve yazılı olmayan kural ve normların betimlendiği ve örneklendiği boyuttur (Göksel vd., 2010). Bu bileşenler bireyin sosyal ihtiyaçlarını tatmin edebilmesi ve tüm toplumun yaşam 
standartlarında önemli iyileşmelere imkân sağlayacak bir ortam oluşturabilmektedir (Abdioğlu ve Yavuz, 2013).

Bilişsel boyut ise paylaşılan dil ve anlatılan hikâyelerden oluşan paylaşılan değerleri ifade etmektedir. Bu boyutta ortak dil yaratılarak çevreye karş1 ortak bir anlayış yapısı oluşturma; bireysel, örgütsel ve toplumsal değerler arasında uyum sağlanmaya çalışılma esas alınmaktadır (Kapu, 2008). Ortaya çıkartılan ortak kültür yapısı ve değerlerle birlikte hareket etme davranışını arttırarak, kişiler arası güven desteklenecek ve bireysel motivasyonların artması sağlanacaktır. Paylaşılan değer ve normlar örgüt üyelerinin birbirleri ile iletişiminde aynı dili konuşmalarına ve aynı bakış açısına sahip olmalarını sağlarken; iletişimde yanlış anlaşılma ve aksaklıkların önüne geçilmesi ve kaynak ve fikir alışverişinin artmasını destekleyen bir ortam oluşturacaktır (Turan, 2013).

Sosyal sermayenin sahip olduğu çok boyutlu özelliğin ölçümlenmesine ilişkin sıkıntıları da ortaya çıkarttığını atlamamak gerekmektedir. Bunlardan ilki toplulukçu ya da bireyci bakış açısıdır. Diğer bir nokta ise gruplar arası ilişkilerin açık-kapalı olması ya da yoğunluğudur. Her iki durumda da birey ya da grupların sahip olduğu hedef, vizyon ve normların anlaşılması konusunda karışıklıklar ortaya çıkabileceği düşünülmektedir. Sosyal sermayenin yeterince yüksek olduğu toplumlarda hedef ve vizyonlar bireysellikten çıkıp toplumsal hale gelecektir (Karagül, 2012). Ayrıca sosyal sermayenin yüksekliğini gösteren unsurların zaten gelişmiş ya da sağlıklı toplumsal yapılarda olmasının gereksiz tekrarlara yol açabileceği ifade edilmektedir (Lin, 1999). Sonuç olarak sosyal sermaye tek başına incelenebilecek kadar bağımsız bir kavram olmaktan çıkmaktadır (Bourdieu, 1986).

\section{SOSYAL SERMAYENİN BİLEŞENLERİ (TEMEL UNSURLARI)}

Sosyal sermayenin yapısal, ilişkisel ve bilişsel boyutları aynı zamanda sosyal sermaye kavramının bileşenlerini de içermektedir. Sosyal sermaye kavramının temelinde ise sosyal norm, güven, sosyal ağlar (karşıllklı ilişkiler) yer almaktadir.

\section{A. Normlar}

Grup üyeleri ve grup faaliyetleri ile ilgili olarak sosyal davranış kalıplarını ve standartlarını belirleyen yazılı ya da yazılı olmayan kurallardan oluşan normlar değerlerin somutlaştırılmış halidir. Toplumdan topluma ya da gruplar 
arasında farklılıklar gösteren normlar, toplumun ya da grupların düzen ve devamlılığını, bireyin davranışlarını belli şekillerde yönlendirerek aykırı durumlarda cezalandırılmasını ve sosyal bütünleşmeyi sağlayan örf, adet, gelenek, din ya da hukuk kuralları bütünüdür.

Normlar, formel kontrol biçimlerinden ya da kurumsallaşmıs yazılı kurallara olan ihtiyacı azaltıp informel bir kontrol sistemi sağlayarak sosyal sermayenin oluşmasında, uygulanmasında ve toplumsal olarak etki göstermesinde rol oynamaktadır (Kapu, 2008). Grup içerisinde bireylerin davranışlarını ya da gruplar arası ağ iletişiminin kurallarını belirleyen normlar aynı zamanda sosyal düzenin oluşmasında da önemli etkiye sahiptir (Kitapçı, 2015). Toplum içerisinde normlarla sağlanan standartlar ya da kurallarla oluşan yapısal ilişkiler daha sağlıklı bir sosyal yapı oluşturmasını sağlayarak insanlar arası bağları güçlendirecek, böylelikle bireysel ve örgütsel amaçların ortaklaştırılmasında önemli adımlar atılmış olacaktır. Bu özelliği ile normlar paylaşılan güven ve karş11ı duygusunun aracı olarak da görülebilmektedir (Kitapç1, 2015).

İnformel normlar yazıya dökülmemiş olmasına karşın, grup örgüt ya da toplum içerisinde hangi davranışların beklendiğini, hangi davranışların değerli olduğunu ve onaylandığını tanımlayarak herkes tarafından anlaşılma ve uyum göstermeyi sağlamaktadır (Onyx ve Bullen, 2000). Aynı zamanda grubun ortak belirlediği davranış kalıplarını ve standartları ile bireyin gelecekte ve sınırlı bilgiye sahip olduğu durumlarda nasıl davranacağını belirleyerek sosyal olarak da bireye destek sağlamakta ve informel kontrol mekanizması oluşturmaktadır (Abdioğlu ve Yavuz, 2013). Oluşan informel ya da formel kontrol mekanizması herkesin kurallara uymasını sağlayarak sosyal sermaye kavramının kalıcılığı arttıracak ve kurumsallaştırılmış kurallara olan gerekliliği ve ek olarak yapılacak hukuksal düzenlemeleri ve yasal cezalandırmayı azaltacaktır (Kitapçı, 2015). Dolayısıyla emredici hale gelen normlar sosyal sermayenin yükselmesi ile gruplar arası bağların güçlenmesine ve güvene dayalı ilişkilerin artmasına yardımcı olmaktadır. Sosyal sermayenin düşük kaldığı grup ya da toplumlarda ise işbirliğinin ancak formel kurallar ve düzenlemelerle yapılabildiği görülmektedir (Kapu, 2008).

\section{B. Güven}

Güven bir kişinin firsat bulduğunda zayıf yanını kendi çıkarları doğrultusunda istismar etmeyeceğine olan inancı olarak tanımlamaktadır (Bilgin ve Kaynak, 2008: 33). Başka bir tanımda ise güven başka insanlarla 
karşılıklı olarak yardımlaşma davranışı içerisinde olacağı veya en azından zarar verici davranışlarda bulunulmayacağı beklentisi ile risk almaya karşı isteklilik olarak ifade edilmektedir (Onyx ve Bullen, 2000: 24). Aynı zamanda güven ortak normlara dayalı, düzenli, dürüst ve işbirliğine yönelik davranışların görüldüğü toplumlarda oluşan beklentiyi de nitelemektedir (Gerşil ve Arac1, 2011: 44).

Sosyal sermayenin oluşmasında rol oynayan ikinci bileşeni güvendir ve güven, sosyal sermaye yazınında önde gelen isimlerin sosyal sermaye tanımlarında önemli bir yer tutmaktadır. Bourdieu (2011), güveni ilişkiler açısından ele alırken, Putnam (2000) ve Coleman (1988) güveni sosyal sermaye içerisinde en kritik unsur olarak görmektedir. Fukuyama ise sosyal sermayenin toplum ya da grupları içerisinde doğan güvenle oluşan kapasite olarak ifade ederek, toplum içerisindeki bireylerin birbirine olan güveni üzerinde durmaktadır (Abdioğlu ve Yavuz, 2013; Gerşil ve Arac1, 2011).

Toplumda güven unsurunun yüksek olması kişiler ve gruplar arası ilişkileri güçlendirmekte, işbirliğine ve katılıma gönüllülüğü arttırmakta ve aynı zamanda açık sistemler oluşturarak öngörülebilirliği arttırmaktadır. Fukuyama (1999), özellikle Taylorist sistemlerdeki yapının güvensiz bir ortam oluşturduğunu dolayısıyla işçiler ve yöneticiler arasında güvensizlik ve firsatçılığın oluşacağını bu durumun ise verimsizlik ve tıkanan iletişim kanallarına yol açacağını ifade etmiştir. Örgütler arası işbirliğinde artan güven sağladığ1 olanaklar, işbirliği yöntemlerini oluşturulması ve geliştirilmesi, grup bağl1lığında çıkarcılığın azaltılması gibi yararlar da sağlamaktadır (Sargut, 2006). Yine örgütler içerisinde oluşturulacak güven ortamının toplum içerisinde ortaklık kurma ya da birlikler kurma yoluyla kolektifleşmeyi sağladığı ve oluşan kolektif yapının farklı kökenlerden insanları bir araya getirip, kaynaştırdığ1; gönüllük, işbirliği hoşgörü gibi değerler kazandırarak zengin bir toplumsal altyapı oluşturacağı da görülmektedir (Bilgin ve Kaynak, 2008). Ayrica toplumun kendine yeterli olması ve kendine olan güveninin yüksek düzeyde bulunması, girişimcilik ruhunun gelişimine ve aynı zamanda üretimde ve ticarette dünya ölçeğinde rekabet gücünün gelişmesine imkân vereceği bilinmektedir (Karagül ve Dündar, 2006).

\section{Sosyal Ağlar}

Sosyal sermaye, bir ağdaki insanlardan, onların birbirine yardım etme isteklerinden ve bu yönde davranma yeteneklerinden oluşur (Özdemir, 2008a). Birey olarak insanlar doğdukları andan itibaren çeşitli ağların 
içindedirler ve hayatları boyunca uzun ya da kısa dönemli, güçlü ya da zayıf bağlantılar kurarak, ağların ortak değer ve normları paylaşmaktadırlar. Sosyal sermaye açısından sosyal ağlar hem kavramın tanımlanmasında kullanılan hem de istenilen sonuçlara ulaşmada sosyal sermayenin nasıl kullanıldığını açıklayan bir değişken olarak ifade edilmektedir (Abdioğlu ve Yavuz, 2013).

Sosyal sermaye ile ilgili önemli bir yaklaşım olan sosyal ağlar yaklaşımı ya da kavramı insanlar, toplum ya da örgütler arasındaki çeşitli işbirliği ilişkileri üzerinde durmaktadır. İki aktör arasındaki bu ilişki enformasyon, tavsiye, dostluk gibi unsurları içerebilirken aynı zamanda güven, ilişkinin süresi ve gücü de önemli kavramlar arasındadır (Çetin, 2006).

Her biri ayrı ağ düzeneği oluşturan örgütlerin diğer örgütlerle sosyal ve ekonomik açıdan bağlantı içerisinde olduğu bilinmektedir. Bu ilişkiler ise tedarikçiler, ticari birliktelikler, kaynak aktarıcılar, yönetim kurulu üyelikleri, çalışanların bireysel ilişkileri ve daha önce kurulan ittifaklardan oluşmaktadır (Paşamehmetoğlu, 2010).

Sosyal ağlar, sosyal sermayenin diğer unsurları olan, güven ve normların etkinliğinin de arttırmakta ve yükselen sosyal sermaye sayesinde ekonomik kalkınma ve refahın oluşmasında önemli bir rol oynamaktadır. Sosyal ağlar sayesinde güven oluşur, paylaşılan değerler gelişir, kontrol maliyetleri azalır ve işlemler kolaylaşır (Karagül ve Masca, 2005; Özdemir, 2008a). Bu noktada sosyal sermayenin yükselebilmesi için gerek toplum gerekse örgütler içerisinde bireylerin değerler ve amaçları paylaşabilmesi ve güven düzeylerinin yüksek olmasını sağlayacak çeşitli ağ özellikleri bulunmaktadır.

Bu özellikleri; ağ kurma davranışları, ağ yoğunluğu, ağ büyüklüğü, ağ merkeziyeti ve ağ farklılığı olarak sıralamak mümkündür. Bu özelliklerden ilki olan ağ kurma davranışı bireyin bireylerin iş veya meslek hayatlarında başarılı olmaları ve işlerini yapmaları için gerekli olan kişilerle ilişki kurmak ve sürdürmek için sergiledikleri davranışları ifade etmektedir (Özdemir, 2008: 85). İkici unsur ise ağdaki kişi sayısını ifade eden ağ büyüklüğüdür. Bir grup ya da örgüt içerisinde bireylerin ilişkide olduğu ya da birlikte çalıştığı kişi sayısını ifade etmekte olan ağ büyüklüğü kişinin ulaşacağı yeni enformasyon, bilgi ve kaynakların niteliğini ve niceliğini etkileyen bir unsurdur (Çetin, 2006). 
Bireyler grup, örgüt ya da toplum içerisinde farklı cinsiyet, eğitim düzeyi, farklı hiyerarşik seviyede ve farklı mesleklerde kişilerle ilisski halindedir. İşte bir ağ içerisindeki bu bireysel özellikler ağ farklılığı olarak adlandırılmaktadır.

Bireylerin diğer bireyler, örgütler ve toplumla kuruduğu ilişkiler birlikte geçirilen zaman paylaşılan, değerlerin büyüklüğü, bilgi alışverişin düzeyi gibi unsurlar açısından ağların güçlü ya da zayıf şekilde oluşmasına neden olmaktadır (Çetin, 2006). Özellikle ağdaki bireylerin birbirini tanıma olasılığ ve iletişim sıklı̆̆ının yüksek olması ağ yoğunluğunun yüksek olmasını ifade etmektedir. Ağ yoğunluğu arttıkça ağ içerisindeki bireylerin özellikleri birbirine yakınlaşarak, birbirlerini tanıma olasılıkları artmakta, ağ yoğunluğu azaldığında ise bireyler farklılaşmaktadır.

Sosyal ağların sahip olduğu diğer bir özellik ise ağ merkeziyetidir. Merkeziyet bireyin ağ yapısındaki konumunu ifade etmektedir. Bireyin ağdaki kişilere yakın olması bireyin ağdaki merkeziyeti olarak açıklanmaktadır. Merkeziyet arttıkça bireylerin elde edeceği sosyal güç, bilgi, yaratıcılık artmakta; örgüt içeresinde merkezi bir konumda olmak ise örgüt içerisinde bireyler arası bir köprü vazifesi oluşturarak sosyal etki alanını genişletmektedir (Özdemir, 2008).

Ağ içerisindeki güven ortamımın yüksek olması bilgi akışının eyleme geçilmesini kolaylaştırdığı için ağ içerisinde oluşan enformasyon kanalları sosyal ilişkiler ağların en önemli unsuru haline gelmektedir (Kitapçı, 2015). Günümüzde ağların sosyal sermayeye katkısı karşılıklı fayda birikimi ile olmakta ve sosyal sermayenin güçlenmesinde aranan yapılar haline gelmesine neden olmaktadır (Seçer, 2009).

Sosyal sermayenin bu üç temel bileşeninin yanında yazında geçen ve sosyal sermayeyi açıklamakta kullanılan farklı kavramlar da bulunmaktadır. Bunlar birlikte hareket etme duygusu, toplulukçuluk, ortak yaşam biçimi, sinerji, sınıfsal yükselme, girişkenlik şeklinde sıralanmakta ve yukarıda ele alınan üç temel kavramla karş1lıklı ilişkiler içerisinde olduğu görülmektedir.

Bireyler sadece kişisel çıkarları için değil toplumsal çıkarlar içinde motive olurlar. Güven duygusuyla oluşan toplumsal normlar, ağ ilişkilerini güçlendirecek aynı zamanda paylaşılan değer ve normların artmasına neden olarak; birlikte hareket etme duygusunu geliştirecek ve toplulukçuluk davranışlarının görülme düzeyini arttıracaktır. Toplulukçuluk kavramı insanların parçası oldukları grubun diğer üyelerinin onları ömür boyu 
gözetme ve sadakat bekledikleri sıkı bir sosyal çerçeveyi tanımlamaktadır (Hofstede vd., 2010). Toplulukçuluk davranışının yüksek olması eşitlik, sosyal adalet, dürüstlük gibi kavramları etkileyerek; oluşacak sosyalleşme ve dayanışma, amaçlara bağlılığın derecesini belirleyecektir. Toplumlar da kültürel değerler bakımından birbirine benzeyen insanlardan oluşacak gruplar, örgüt ve toplumların bireylerin üstünde olduğu inancı ve sahip olunan ortak dil de güçlü iletişim ağlarının oluşması sağlanacaktır.

Sosyal ağların güçlü olması ağ içerisindeki bireylerin eğitim, ortak değer ve normlar, gelir seviyesi pek çok açıdan benzerlik gösterdiğini işaret etmektedir. Birbirine benzer özellikler gösteren kişiler oluşan sosyal adalet ve dürüstlük gibi kavramların etkisiyle de güven ortamının oluştuğu ortak yaşam biçimleri tercih edecek ve tercih edilen yaşam biçimleri de ağlara giren birey sayısını arttırarak daha geniş ve güçlü ağlar oluşmasını sağlayacaktır. Birlikte hareket etme duygusu ve güçlenen ağlar toplumsal işbirlikleri ve iş grupları arasındaki ilişkiyi pozitif yönde etkileyecektir. Bu pozitif etki devlet, kamu ve özel sektör örgütleri ve sivil faaliyetler arasındaki ilisskilerinde olumlu yönde etkileyerek birbirlerinin tamamlayarak sinerji oluşmasına yardımcı olacaktır (Çetin, 2006). Ayrıca bireyler arası ilişkilerin güçlenmesi de bireyler ve gruplar arasinda sinerji yaratacaktır.

Belirli hedefler ulaşmak için oluşturulan örgütler kişilerin ortak amaçlar için işbirliği yapmalarını sağlayacak, üyelerine ekonomik ve sosyal alanda pek çok yarar getirmektedir (Karagül ve Masca, 2005). Üye olunan grubun diğer gruplarla arasındaki ilişkiler bireylerin üye oldukları grup sayısını da etkileyerek kendilerinin ve kariyerlerinin gelissiminde de etkili olacaktır. Ayrıca bir gruba üye olmanın getirdiği avantajlar kişilerin bireysel hedef ve amaçlarını gerçekleştirmesinde rol oynayarak sınıfsal olarak yükselmelerini sağlayacaktır.

Toplum içerisinde gönüllülük beklentisi, yardımlaşma, gönülsüzlüğe karş1 olan negatif bakış, karar mekanizmasına, katılım emeğinin karşılığını alacağ1 düşüncesi gibi pek çok konuda bireyleri destekleyerek; bireylerin gerek kendine gerekse içerisinde bulundukları topluma olan güvenlerini de arttıracaktır. Kendine ve topluma olan güveni artmış bir birey ise çevresine karşı daha atak olacak ve daha yüksek gönüllülük davranışı ile yaratıcılık ve girişimcilik özelliklerini kullanmaya istekli olacaktır. 


\section{IV. ÖRGÜTLERDE SOSYAL SERMAYE KAVRAMI}

Sosyal sermaye kavramı tanımlarından da anlaşılabileceği gibi çok boyutlu bir kavramdır. Bazı tanımlarında sosyal sermayenin aktörler ve diğer aktörler arasındaki ilişkiler üzerinde durulmuşken bazı çalışmalarda ise toplumdaki ilişkilerin yapısı ile açıklamaya çalışılmaktadır (Sargut, 2006). Sonuç olarak sosyal sermaye kavramı ağlar içerisinde olan sosyal ilişkilerden bir takım faydalar edilmesi ve önemli kaynaklara ulaşmasını incelemektedir (Özdemir, 2008a).

Aynı zamanda yapılan çalışmalar göstermektedir ki sosyal sermaye kavramı bireyler ve örgütlerden başlayıp, bölgeler, toplumlar ve uluslar olmak üzere farklı düzeylerde incelenmekte ve etkilerini sürdürmektedir. Elde edilecek bu kaynaklar hem bireyleri hem örgütleri hem de siyasi kurumlar ya da devleti de içerecek şekildedir. Bu nedenle örgütsel sermaye üç farklı boyutta tanımlanabilmektedir. Mikro düzey birey ve aile, mezo düzey örgütsel ve makro düzey de devlet ve siyasi kuruluşları içermektedir (Kırel vd., 2016). Elbette ki bu düzeyler birbirleriyle kesin sınırlarla ayrışamamaktadır. Bunun nedeni ise birey, grup ve toplumların birbirini kapsaması ve sürekli etkileşim içerisinde olmasıdır.

Örgüt içerisindeki çalışanların yöneticilerle ve birbirleriyle ilişkileri, hem de örgütün diğer örgütlerle, müşterilerle, tedarikçilerle olan ilişkileri o örgütün sosyal sermayesini oluşturmaktadır (Özdemir, 2008). Özetle örgüt içerisinde üyelerin birbirleriyle ve diğer paydaşlarla olan ilişkiler ağı örgütsel sosyal sermaye olarak tanımlanabilmektedir. Bu noktada örgüt çalışanlar arasındaki ortak değer ve normları içeren örgüt içi ilişkiler içsel sosyal sermayeyi oluşturmaktadır. Örgütün üretim faaliyetleri ve pazar ile olan bağlantılarını oluşturan müşteriler, tedarikçileri, sivil toplum kuruluşları, diğer özel ve kamu kuruluşları ile olan ilişkileri ise dışsal sosyal sermaye olarak tanımlanmaktadır.

Tabi ki örgütün sahip olduğu sosyal sermaye çalışanlarının parçası olduğu toplumsal sermayenin ayrılamaz bir parçasını da oluşturmaktadır. Dolayısıyla örgütsel sosyal sermaye sosyal sermayeden çok da büyük farklılıklar göstermeyecektir. Örgütsel sosyal sermaye kavrama örgüt içerisinden bir bakış kazandırarak bireylerin kişisel kazançlarından çok, paylaşılan amaç ve hedefler ve örgüt içerisindeki sosyal ilişkileri ile başlayan; çalışanların kendi aralarında ve yönetimle olan ilişkileri ile artan kazanımları ifade etmektedir (Erbil ve Öğüt, 2016). 
Bu noktada sosyal sermayenin örgütsel davranış çalışmaları açısından da önemli bir kavram olduğunu söylemek mümkündür. Zira günümüz işletmelerinde vizyonun paylaşılır hale getirilmesi, ortak örgüt kültürü oluşturabilmek, çalışanların motivasyonları sağlamak, iş gücü tatmini, örgütsel bağlllık, dış çevre ile ilişkilerin düzenlenmesi gibi pek çok konuda sağlanan başarılar değişen ve gelişen çevre ile uyumu kolay bir şekilde sağlamak için önem kazanmaktadır. Örgütün sosyal sermayesinin yüksek olması bu uyumun daha kolay ve hizlı olmasına yardımcı olacaktır.

Örgütün örgütsel sosyal sermayesi yüksek olması ve örgüt içerisindeki bireylerin ilişkilerinin gücü birbirleri ile karş1lıklı ilişkili kavramlardır. Bu durum öncelikle örgütsel hedef ve amaçların, bireysel hedef ve amaçlarla ne düzeyde ilişkilendirilip bireysel amaçların örgütsel amaçlara dönüşmüş olması ile ilgilidir. Bu noktada örgütsel güven ve bağl1lık artacak, örgüt içerisinde çıkacak olan çatışmaların önüne geçilebilecektir. Paylaşılan hedef ve amaçlar örgüt içerisinde üyelerin ortak bir dil geliştirmesini sağlayarak örgütsel değer ve normların aktarılmasına yardımcı olacaktır. Örgütsel değerler içerisinde saklı olan önemli ve zımni bilgilerin ise örgüt içerisinde tutulması sağlanacaktır (Erbil ve Ögüt, 2016).

Sosyal sermayenin temelinde üyelerine daha iyi yaşam sağlaması fikri bulunmaktadır (Turan, 2013: 68). Bu açıdan örgütsel sermayenin yüksek olması bireylere de çeşitli katkılar sağlayarak örgütleri olumlu yönde etkileyecektir. Bireylerin sahip olduğu ağ sayısının artması onların daha fazla kaynağa ulaşmasına, alacağı yardımların ve karş1lılılık derecesinin artması anlamına gelmektedir. Paylaşlan hedefler ve dil ile birlikte üye oldukları ağ sayısını arttıran bireyler ya da örgüt üyeleri kariyer fırsatlarını arttırarak iş bulma konusunda kolayliklar sağlayabilmektedirler (Turan, 2013). Ortak çalışmayla bireysel hedef ve amaçlara ulaşılabileceği düşüncesi çalışanların performansını, örgüt içerisinde sahip oldukları gücü arttırarak örgütsel bağlılık yaratmakta, örgütten ayrılmaların azalmasına yardımcı olmaktadır.

Örgüt içerisinde paylaşılan dil sayesinde bilgi ve enformasyon paylaşımı artacak, gerekli bilgi ve enformasyona zamanında ulaşma mümkün kılınacak, öğrenme kolaylaşacak, kolaylaşan öğrenme ise yenilik ve değişime açık bir ortam oluşturarak uyum sağlamayı kolaylaştıracaktır. Sosyal sermayesi yüksek olan örgütlerde kaynakların ve bilginin birimler arasında değişimi kolaylaşacak, birimlerin birlikte hareket etmesi, ortak kararlar alınması ve 
alınan kararların daha kolay uygulanması sağlanacaktır. (Erbil ve Öğüt, 2016).

Örgüt içerisinde bilgi ve enformasyon akışını hızlandıran diğer bir unsur ise gruplar arası iletişimdir. Gruplar ne kadar fazla farklı grupla iletişime geçerse örgüt içerisindeki güven ortamı ve karş1lıklılık beklentisi gelişecek ve örgütsel verimliliğe doğru giden bir ortam oluşacaktır. Ayrıca gruplar içerisindeki ilişkilerin düzeyi yakınlaştıkça gruba ve örgüte karşı aidiyet de artacaktır (Turan, 2013). Dolayısıyla örgütsel sosyal sermayenin sosyal sermaye kavramına örgütsel düzeyde bir farklı bakış kattığını söylemek mümkündür.

Sosyal sermaye içinde çalışma, işbirliği, uyum, dürüstlük, ortak paylaşım, beşeri ilisskiler, sosyal dayanışma gibi sosyal erdemleri barındırmaktadır (Gerşil ve Arac1, 2011). İnsanlar arasındaki bağlılığı, sadakati, işbirliğini, bilgiye ve yeteneğe hızlı erişimi ve düzenli bilgi aktarımı ile örgütsel davranışı destekleyerek, aynı zamanda sosyal ağlar, güven ve normlarla örgütsel davranış çalışmalarıyla da ortak bir yapı sergilemektedir. Ayrıca sosyal sermayenin etkilerini sadece makro boyutta değil mikro boyutlarda da görmek mümkün olmaktadır. Özellikle işletme büyüklüklerinin artmasında, çalışan verimliliğinin çoğalmasında sözleşme ihlallerinin azalmasında işlem maliyetlerinin düşmesinde sosyal sermayenin önemli etkileri bulunmaktadır (Karagül ve Dündar, 2006).

Son yıllarda yapılan çalışmalar incelendiğinde ülkemizde sosyal sermaye çalışmaların ağırlıklı olarak iktisat-ekonomi alanında kavramsal olarak tanımlandığı ve sosyal sermayenin nasıl hesaplanacağına dair çalışmalarla yer aldığı, yönetim ve örgütsel davranış çalışmalarında ise gerektiği kadar yer bulmadığ1 görülmektedir. Yönetim alanında yapılan çalışmalarınsa örgütsel davranışla birebir ilgili olmadığı, çok azının örgütsel davranış alanı ile kesiştiği dikkat çekmektedir.

Yönetim alanında sosyal sermaye ile ilgili yapılan çalışmalardan biri Sargut (2006) tarafından yapılmıştır. Çalışmada sosyal sermaye kavramına içerisinde yer alan ağ düzeneği kuramı açısından bakarak sosyal sermaye ve ağ düzeneği kuramının kesiştiği noktalar incelenmiştir. Çalışma sonucunda ortaklaşa davranışa sahip toplumlarda oluşan yapısal boşlukların bilginin yayılmasında ve aracılık rollerinin gelişmesinde önemli olduğu; ülkemizdeki sosyal yap1 dolayısıyla oluşmuş bu boşlukların sosyal sermayenin geliştirilmesinde önemli rol oynayacağı tartışılmıştır. 
Toplumsal sermayeye örgütsel açıdan bakan diğer bir yaklaşım Özen ve Aslan (2006), tarafından Ankara'da yapılmış çalışmadır. Yazarlar çalışmada Ankara Ortadoğu Sanayi ve Ticaret Merkezi'nde (OSTIM) faaliyet gösteren işletmeleri, örgütler arası ilişkiler açısından incelemişlerdir. Çalışma sonucunda dışsal sermaye yaklaşımında sunulduğu gibi işletme sahiplerinin karşılıklı ekonomik çıkar temeline dayalı olarak zaman içerisinde oluşan arkadaşlık bağları yoluyla güven oluşturulabildiği ve sosyal sermaye yaratılabildiği görülmektedir.

Özdemir (2008), çalışmasında çalışanların iş tatminlerinde örgütsel sosyal sermayenin ne düzeyde belirleyici olduğunu araştırmıştır. Çalışma sosyal sermaye ve iş tatmini ilişkisinin güven, özdeşleşme, sosyal destek, yükselme, ücret artış1, iş performansı, yeni ve önemli bilgilere ulaşma açısından kavramsal bir model önerisi sunmaktadır. Özdemir aynı yıl yayınladığı diğer bir makalesinde ise sosyal ağ özellikleri açısından sosyal sermayenin bilgi yaratma özelliğini incelemiştir. Yazar bu çalışmasında ise Türkiye'deki başarılı 6 üniversitede fen bilimleri ve sosyal bilimler alanında çalışan akademisyenlerin sosyal ağ özellikleri ve güven boyutlarının makale sayıları üzerindeki etkisi ölçmüş ve sosyal sermaye ve bilgi yaratma arasındaki ilişkinin bilim dallarına göre farklılıklar gösterdiği sonucuna ulaşmıştır.

Kapu (2008), sosyal sermayenin beşeri sermaye ve kültürel sermaye gibi diğer sermaye türleri ile olan ilişkisi tartışarak örgütsel ve toplumsal yapılar için öneminin vurgulamayı amaçlamıştır. Çalışmada farklı sermaye türleri incelenerek organizasyonlarda öngörü kavramı açıklanmış, sonuç olarak sosyal sermayenin davranış etkinliğini ve işletme organizasyonlarının örgütsel ve yönetimsel olarak performanslarını arttırdığı; öğrenme yaratıcılık ve işbirliği davranışını cesaretlendirerek organizasyonlarda öngörü yeteneğinin gelişmesinde etkili olduğu ifade edilmiştir.

Bilgin ve Kaynak (2008), çalışmalarında sosyal sermaye faktörlerinin üniversite çalışanlarının iş başarılarına etkilerinin incelemişlerdir. Mustafa Kemal Üniversitesinin akademik ve idari toplam 164 çalışanı üzerinde yaptıkları anket uygulaması sonucunda, üniversite çalışanlarının iş başarısı üzerinde etkin olan faktörlerin; yerel topluma katılım, sosyal faaliyetlere katılım ve aile-arkadaşlık ilişkileri olduğu görülmüştür.

Arıcıŏlu ve Ergin (2009), çalışmalarında güven, sosyal ağlar içerisinde olma ve ilişkiler gibi sosyal sermaye değerlerinin Konya Sanayi Bölgesinde sahip/yöneticiler üzerinden değerlemeyi amaçlamışlardır. Sonuçta incelenen 
bu üç boyutun Konya ili sosyal sermayesinin yükselmesinde etkili olduğu görülmektedir.

Örgütlerde bilgi paylaşma davranışı ve sosyal sermaye kavramları bu konuda yapılan çalışma konularından bir diğeridir. Göksel vd. (2010), çalışmalarında sosyal sermaye boyutlarının bilgi paylaşma davranışı ve içsel ve dişsal kontrollolügün örtülü bilgi paylaşım davranışını etkileyip etkilemediğini incelemişlerdir. Bu çalışma verileri bir üniversite hastanesi intörnleri ile yapılan anket ile elde edilmiş ve sonuçta sosyal sermaye boyutlarının ve içsel kontrolülüğün örtülü bilgi paylaşımını olumlu yönde etkilediği görülürken, dışsal kontol ile örtülü bilgi paylaşımı arasında bir ilişki bulunmamıştır.

Kültürel değerlerde farklılaşmanın sosyal sermayeye etkileri üzerine yapılan bir çalışma da Paşamehmetoğlu (2010) tarafından yapılmıştır. Çalışmada içsel ve dişsal sosyal sermaye düzeyinin kültürel değerlere bağlı olarak ne ölçüde değişeceği Ankara Mobilyacılar Sitesi (Siteler) ve OSTiM sanayi bölgelerinde yapılan anket çalışması ile araştırılmıştır. Araştırma sonucunda, kültürel değer boyutlarının değişkenlerin birçoğunu etkilemediği, sadece yatay bireycilik ile dışsal sosyal sermaye arasında ve dikey toplulukçuluk ile duygusal güven arasında pozitif ilişki olduğu ortaya çıkmaktadır. Bunların dışında elde edilen diğer bir sonuç iç gruba güven ile içsel sosyal sermaye arasında pozitif ilişki olduğu şeklindedir.

Başak ve Öztaş (2010), çalışmalarında bir sosyal sermaye unsuru olarak yaratılan güvenin, toplumsal cinsiyet ve sınıf esasında bir farklılaşmaya uğrayıp uğramadığını araştırmayı amaçlamışlardır. Bir kamu bankası, bir sivil toplum kuruluşu ve özel hukuka dayalı bir bankanın idari mali işler personelinden toplanan verilerin analizi sonucunda, güven ağları esasında sosyal sermayenin oluşumunda öncelikli belirleyicinin ait olunan sınıf olduğu görülmüştür.

Aydıntan ve arkadaşları (2010), Gazi Üniversitesi Tıp Fakültesi altıncı sınıf öğrencilerinden (intörn) elde ettileri verilerle sosyal sermayenin "yapısal", "bilişsel" ve "ilişkisel" boyutlarının, bu boyutların alt bileşenleriyle beraber örtülü bilgi paylaşım niyeti üzerindeki etkilerinin araştırılmasını amaçlamışlardır. Çalışma sonucunda sosyal sermayenin ve içsel denetimin, örtülü bilgi paylaşım niyetini pozitif olarak arttırdığı ve bireylerin örtülü bilgi paylaşım niyetlerinin, örtülü bilgiyi paylaşma davranışına dönüştüğü sonucuna ulaşılmıştır. 
Gerşil ve Aracı (2011), çalışmalarında sosyal sermayenin güven unsurunun iş görenlerin performansı üzerine etkilerini incelemişlerdir. Çalışma Bursa ili Organize Sanayi Bölgesinde otomotiv sektöründe faaliyet gösteren firma çalışanları üzerine yapılmıştır. Çalışma sonucunda sırasıyla çalışanların birbirlerine, yöneticilerine ve firmaya duydukları güvenin performans düzeyleri ile pozitif ilişkili olduğu görülmektedir.

Arslan (2012), çalışmasında Sakarya PTT Başmüdürlüğü çalışanlarından anket ile elde ettiği verilerle, kurumsal verimlilik ve performans ile beşeri ve sosyal sermayenin etkin kullanımı arasındaki ilişkiyi incelemeyi amaçlamıştır. Çalışma souncunda insan ilişkileri ve beşeri-sosyal sermayenin geliştirilmesine yönelik gösterilen öncelikli çabaların; kurumsal verimlilik ve performansın arttırılmasında etkili olduğu sonucuna ulaşılmıştır.

Gerni (2013), İlişkilerin Maddi Yönü Sosyal Sermaye ve Örgütsel Boyutu isimli kitabında sosyal sermayenin kavramsal bir tanımlamasını yaptıktan sonra, örgütsel sermayenin artttırılması kapsamında örgütsel vatandaşlık davranışı ve sosyal sermaye ilişkisi incelenmiş, örgütsel vatandaşl1k davranış1 oluşturulmasının örgütsel sosyal sermayeyi nasıl geliştirebileceği üzerinde durulmuştur.

Turgut ve Begenirbaş (2013), çalışmalarında hastanelerdeki sosyal sermaye ve yenilikçi iklimin yenilikçi davranışa etkisi araştırmışlardır. Çalışma Kütahya ilinde faaliyet gösteren iki kamu hastanesi ve iki özel hastanedeki 398 çalışana uygulanan anket verilerinin analizi ile gerçekleştirilmiştir. Sonuçta yapısal sosyal sermaye ve bilişsel sosyal sermayenin yenilikçi iklim boyutları ve yenilikçi davranışa anlamlı etkisi bulunamamış; ilişkisel sosyal sermayenin ise yenilikçi iklim boyutlarını ve yenilikçi davranışı olumlu ve güçlü bir şekilde etkilediği saptanmıştır.

Sosyal sermaye ile ilgili yapılan bir diğer çalışmada da sosyal sermayenin bilgi paylaşma tutumuna etkisi, motivasyonun bu etkideki rolünü araştırma ve çalışanların demografik özellikleri açısından sosyal sermaye, bilgi paylaşma tutumu ve motivasyonlarında bir farklılık olup olmadığının incelenmesi amacıyla yapılmıştır (Turan, 2013). Çalışmada Türkiye'de telekomünikasyon sektöründe bulunan firmalardan anket yardımıyla toplanan veriler analiz edilerek; sosyal sermayenin bilgi paylaşma tutumu ve motivasyon üzerinde pozitif yönde ve anlamlı düzeyde etkili olduğu sonucuna ulaş1mıştır. 
Taştan (2015), örgütsel güven ve sosyal adalet algısının bireylerin bulundukları kurumdaki sosyal sermaye yapısına yönelik değerlendirmelerini inceleyen çalışmasında, ilk, orta ve lise düzeyindeki eğitim kurumlarında çalışan öğretmen ve idarecilere uyguladıkları anket çalışması ile ölçmüştür. Araştırma sonucunda örgütsel güven ve sosyal adalalet algısının sosyal sermaye ile aynı yönde ilişkilere sahip olduğu sonucuna ulaşılmıştır.

Tunçay ve arkadaşları (2015), yerel yazında kısıtlı olan sosyal sermaye odaklı makalelerin bilgi ağını sosyal ağ analizi ile görselleştirme amacı ile yola çıktıkları çalışmalarında, yazında yönetim ve organizasyon alanında yazılmış ve anahtar kelime içeren kavramları, sosyal ağ analizi yönteminde kullanılan belirli ölçütler çerçevesinde değerlendirmişlerdir. Çalışma sonucunda "ağ kuramı" ve "güven" kavramlarının yüksek derece, arasındalık ve yakınlık merkeziliğe sahip olduğu bulgusuna ulaşmışlardır.

Kırel ve arkadaşları (2016), çalışmalarında performans yönetimi sosyal sermaye arasındaki ilişkiyi incelemişlerdir. Eskişehir'de faaliyet gösteren kamu ve özel bankaları kapsayan bu araştırma uygulamalarının ayrı ayrı tüm aşamaları sosyal sermaye ile ilişkileri açısından incelenmiştir. Çalışma sonucunda örgütsel sosyal sermaye ve performans yönetimi arasında doğrudan ve olumlu bir ilişkinin olduğu ve motivasyonun bu ilişkide kısmi aracılık etkisinin bulunduğu ifade edilmektedir. Ayrıca örgütsel sosyal sermayeyi performans değerlendirme, ücret, işten ayrılma ve motivasyon gibi boyutların yüksek düzeyde etkilediği, terfide ise orta düzeyde bir etki büyüklüğüne sahip olduğu ortaya konmuştur.

Erbaş1 ve Sanioğlu (2016), sosyal sermayenin örgütsel bağlllık üzerindeki etkisinde örgüt depresyonunun arac1lık rolünü incelemek amaciyla Konya'da otomotiv yan sanayi alanında faaliyet gösteren işletme çalışanları üzerinde anket çalışması yapmışlardır. Araştırmanın sonucunda sosyal sermaye, örgüt depresyonu ve örgütsel bağlılık değişkenleri arasında istatistiksel açıdan anlamlı ilişkiler görülmüştür. Ayrıca sosyal sermayenin örgütsel bağlılık üzerindeki etkisinde örgüt depresyonunun tam aracılık etkisinin olduğu tespit edilmiştir.

Yıldız ve arkadaşları (2016), sosyal sermayenin etik liderlik davranışı ile olan ilişkisini incelemek üzere Ardahan Üniversitesi'nde çalışan öğretim elemanları üzerinde nicel bir araştırma yapmışlardır. Yazarlar araştırma sonucunda etik liderlik davranışı ile çalışanların sosyal sermaye algıları arasında olumlu yönde anlamlı ilişkiler bulmuştur. Bununla birlikte, en yüksek ilişkinin ise 
sosyal sermayenin alt boyutlarından yapısal sosyal sermaye ile etik liderlik davranışı arasında tespit edildiği görülmektedir.

Tuncay (2016), yöneticilerin liderlik davranışlarının sosyal sermaye üzerindeki etkisini incelemiştir. Bu ilişki Konya il merkezi sınırları içerisinde inşaat sektöründe faaliyet gösteren işletmelerin orta ve üst kademelerinde çalışan yöneticilerden anket yardımıyla toplanan veriler incelemişlerdir. Araştırmanın sonucunda, etkileşimci liderlik tarzının sosyal sermaye üzerinde bir ilişkisi bulunmazken, dönüşümcü liderlik tarzı ve sosyal sermaye arasında pozitif yönlü, anlamlı bir ilişki tespit edilmiş, yöneticiler tarafından dönüşümcü liderlik tarzının benimsenmesi, sosyal sermaye düzeyini etkili bir şekilde arttırdığ görülmüştür.

Yapılan yazın taraması göstermektedir ki sosyal sermaye kavramının Türkiye'deki yönetim ve örgütsel davranış yazınlarındaki geçmişi on yılın az üzerindedir. Çalışmaların ilk yıllarda daha kavramsal ağırlıklı olduğu günümüze yaklaştıkça görüşme ve anket gibi saha çalışmaları yapılarak konunun incelendiği görülmektedir. Özellikle nicel çalışmalarda sosyal sermayeyi ölçmek için Gloshal'ın farklı meslektaşları ile yaptığı çalışmalardan geliştirilen anketlerden yararlanıldığı (Aydıntan vd, 2010; Göksel vd, 2010; Turgut ve Begenirbaş, 2013; Taştan, 2015; Kırel vd, 2016; Tuncay, 2016); baz1 çalışmalarda sosyal sermayenin içerdiği ağlar, güven gibi sadece alt unsurları ölçen ölçekler kullanıldığı (Paşamehmetoğlu, 2010; Gerşil ve Arac1, 2011; Bilgin ve Kaynak, 2008) görülmektedir. Bir kısım araştırmacıların ise yazında sıklıkla kullanılan anketleri (Arıcığlu ve Ergin, 2009; Yıldız vd, 2016; Erbaş1 ve Sanioğlu, 2016) ya da kendi geliştirdikleri anketleri kullandıkları dikkat çekmektedir. Nitel araştırma yöntemleri ise sosyal sermaye araştırmalarında nadiren karşılaşılan bir yöntem olduğu görülmektedir.

\section{SONUÇ}

Sosyal sermaye kavramı güven, ilişkiler ve örgüt içi normlardan oluşan bir kavramdır. Dolayısıyla örgütler ve toplum içinde gruplar ve insanlar arası ilişkilerin düzenlenmesini ve ilişkilerin niteliğini etkilemektedir. Gerek dünya gerekse Türkiye'deki yazını bunu destekler niteliktedir.

Türkiye'de sosyal sermaye kavramının tartış1ldığ çalışmaların ağırlıklı iktisat ve sosyoloji alanında olduğu görülmektedir. Ancak örgütler düzeyinde de önemli değişken olması bakımından sosyal sermaye kavramının makro bakış açısından sıyrılıp, bu kavrama mikro yani örgütsel düzeyde bir bakış açısını 
kazandırılması gerekmektedir. Bu nokta Tunçay vd. (2015) tarafından yapılan çalışmada da sosyal sermaye ile ilgili yayın sayılarının özellikle yönetim ve organizasyon yazını açısından sınırlı olduğu, çalışmalarında bilgi ağındaki evriminin süreçsel olarak sorgulama konusunda sıkıntılar yarattığı şeklinde ifade edilmiştir. Bu noktada farklı sektörlerde ve kamu kuruluşlarında yapılacak çalışmaların sayılarının artması ve belirli zaman aralıklarıyla tekrar edilerek veri birikiminin sağlanması konunun incelenmesi ve analizini kolaylaştıracaktır.

Sosyal sermayenin yüksek olduğu bir toplumda sosyal ve ekonomik kalkınmanın sağlanması daha kolay olmaktadır. Benzer şekilde sosyal sermayenin düzeyi örgütlerin sürdürülebilirlik ve değişime uyum sağlama yeteneğini etkilemektedir. Bu noktada sosyal sermayenin örgüt içi unsurlarla karş1lıklı ilişki içerisinde olduğu görülmektedir. Yazındaki çalışmalar göstermektedir ki sosyal sermayenin düzeyi çalışan motivasyonu, örgütsel güven, iş başarısı, örgütsel vatandaşlık davranışı, liderlik şekli, yenilikçi davranış, örgütsel bağlılık gibi pek çok konuda örgütsel yapıyı etkilemektedir. Dolayısıyla örgütlerin kullandıkları performans yönetimi, kariyer yönetimi, motivasyon teknikleri ve liderlik biçimleri gibi pek çok değişkenin sosyal sermaye ile karşılıklı ilişkili olan değişkenler olarak incelenmesi alana inceleme unsuru olarak yeni değişkenler sağlayacaktır.

Sosyal sermeyenin gerek toplumsal kültür gerekse örgüt kültürü ile yakından ilişkili olduğu açıktır. Bir toplumun toplumsal ya da örgütsel kültür yapısının sosyal sermaye ile karşılıklı ilişkili olması kültürler arası karşılaştırmaya imkân sağlayacak yeni araştırma yöntemlerini ve değişkenlerin araştırılmasını gerektirmektedir.

Günümüzde örgütsel davranış çalışmalarının temelinde değer yaratabilme, değişen çevreye uyum sağlayabilme yeteneği geliştirebilme, rekabete dayanıklı yapılar oluşturma vardır. Bu amaçla çalışmalar, örgüt yapısını, çalışan özelliklerini, çalışan-çalışan ve çalışan-yönetici ilişkilerinin optimal yapısını araştırmaktadır. Bu noktada örgüt içerisinde kurulan ilişkiler sosyal ağlar, amaç ve değerlerin paylaşılması örgütsel güven gibi sosyal sermaye unsurlarının ne derece yüksek olduğuyla da yakından ilişki olduğu görülmektedir. Sosyal sermaye kavramı iş tatmini, istihdam süreçleri, motivasyon, örgütsel güven gibi pek çok örgütsel kavramın belirleyicisi olarak örgütsel davranış alanında kullanılması gerekli bir değişken halini almaktadır. Ayrıca yapılan çalışmalarda sektör içerisindeki ilişkilerin de 
dikkat alınarak dış paydaş/çevre kavramına gereken önemin verilmesi gerekmektedir. Bu noktada sosyal sermeyenin ölçümü için sektörler bazında belirlenecek yeni değişkenler, sektörel ve kurumsal stratejilerin geliştirilmesinde de önemli rol oynayacaktır.

Sosyal sermayenin ölçümlenmesinin de çözümlenememiş olması ve Türkiye'deki sosyal sermaye ölçüm araçların dünya yazınından alınması da dikkat çekici bir unsur olmaktadır. Yazın incelemesinde ele alınan çalışmaların birçoğu sosyal sermaye ölçüm unsurlarının toplumdan topluma farkl1lık gösterebileceğini göz ard1 etmektedir. Türkiye gibi toplulukçuluk özellikleri gösteren bir ülkede sosyal sermayenin ve sosyal güven değerinin beklenenin aksine düşük çıkması bunun önemli bir göstergesidir. Sosyal sermaye ve sosyal değerlerin yükselmesi ise güven eksikliği dolayısıyla aile şirketlerinin yoğun olarak karşılaşıldığı ülkemizde kurumsallaşmaya yönelik önemli adımların da atılması sağlanacaktır. Ayrıca yapılan çalışmaların inşaat, mobilya, otomotiv, sağlık, eğitim, telekomünikasyon, bir kısım kamu ve sivil toplum kuruluşları ve bankalar gibi farklı sektörler içerisinde yapıldığı görülmektedir. Bu durum elde edilen sonuçların ülke çapında genelleştirilmesinin ve yorumlanmasının önüne geçmektedir. Sosyal sermaye alanında ileride yapılacak çalışmalarda farklı sektörlerdeki sosyal sermaye yapısının ölçümlenmesi ve Türkiye'nin kültürel, sosyal ve ekonomik unsurlarını da içeren bir ölçüm tekniğinin geliştirilmesi açısından yararlı olacaktır. Ayrıca belirlenecek yeni değişkenler kamu kurumları ve özel sektör ilişkilerini farklı bir yapıya taşıyarak bu gruplar arsında sinerji yaratılabilmesine olanak sağlayacaktır.

Sosyal sermaye kavramının farklı bir bakış açıları ile incelenmesi ve örgütsel davranışçıların diğer bilim dallarındaki araştırmacılarla yapacakları ortak çalışmalar Türkiye'deki sosyal sermaye yapısının daha net ortaya konmasında da yardımcı olacaktır.

\section{KAYNAKÇA}

ABDIOĞLU, H., ve Yavuz, S. (2013). İșletmelerde Sosyal Sermayenin Ölçümlenmesi ve Raporlanmasına Yönelik Bir Araştırma. Afyon Kocatepe Üniversitesi İ̈BF Dergisi, 15(1), 25-56.

ARICIOĞLU, M. A., ve Ergin, R. A. (2009). Güven ya da Sosyal Sermaye Nedir?: Konya Sanayi Bölgesinde Sahip/Yöneticiler Üzerine Bir Araștırma. Selçuk Üniversitesi Sosyal Bilimler Enstitüsü Dergisi, 21, 25-43.

ARSLAN, A. (2012). Beşeri - Sosyal Sermayenin Uygun Kullanımının Kurumsal Verimliliğe ve Performansa Etkisi "Sakarya PTT Başmüdürlüğü Çalışanları ile Uygulamalı Bir Çalışma”. Akademik Íncelemeler Dergisi, 7(1), 227-254.

AYDINTAN, B., Göksel, A., ve Bingöl, D. (2010). Örtülü Bilgi Paylaşım Niyeti Üzerinde Sosyal Sermaye ve Denetim Merkezi Odaklılığının Rolü: Hekimlikte Bir Alan 
Araştırmas1. Gazi Üniversitesi İktisadi ve İdari Bilimler Fakültesi Dergisi, 12(1), 1-26.

BAŞAK, S., ve Öztaş, N. (2010). Güven Ağbağları, Sosyal Sermaye ve Toplumsal Cinsiyet. Gazi Üniversitesi İktisadi ve İdari Bilimler Fakültesi Dergisi, 12(1), 27-56.

BİLGİN, N., ve Kaynak, R. (2008). Sosyal Sermaye Faktörlerinin İş Başarısına Etkisi: Üniversite Çalışanları Üzerine Ampirik Bir Çalışma. C.Ü. Sosyal Bilimler Dergisi, 32(1), 29-38.

BOURDİEU, P. (1986). The Forms of Capital. J. E. Richardson içinde, Handbook of Theory of Research for the Sociology of Education (s. 241-258). New York: Greenwood.

BOURDİEU, P. (2011). the Forms of Capital. I. Szeman, ve T. Kaposy içinde, Cultural Theory an Anthology. John Wiley \& Sons.

COLEMAN, J. S. (1988). Social Capital in the Creation of Human Capital. The American Journal of Sociology, 94, 95-S120.

ÇETİN, M. (2006). Bölgesel Kalkınmada Sosyal Ağların Rolü: Silikon Vadisi Örneği. Dokuz Eylül Üniversitesi İ.I.B.F. Dergisi, 21(1), 1-25.

ERBAŞI, A., ve Sanioğlu, Z. (2016). Sosyal Sermayenin Örgütsel Bağlılık Üzerindeki Etkisinde Örgüt Depresyonunun Arac1lık Etkisi. BJSS Balkan Journal of Social Sciences /, 860-867.

ERBİL, C., ve Öğüt, A. (2016). Örgütsel Sosyal Sermayenin İnşasında Çalışanların Değișen Rolü: Richard Sennett'ın Perspektifinden Yeni Kapitalizm Örgütlerine Bak1ş. Gazi Üniversitesi İktisadi ve İdari Bilimler Fakültesi Dergisi, 18(1), 192216.

FUKAYAMA, F. (1999). Social Capital and Civil Society. IMF Conference on Second Generation Reforms. Washington.

GERNİ, M. (2013). İişkilerin Maddi Yönü Sosyal Sermaye ve Örgütsel Boyutu. İstanbul: Beta.

GERŞİL, G. S., ve Arac1, M. (2011). Sosyal Sermayenin Güven Unsurunun İşgörenlerin Performansı Üzerine Etkileri. Çalışma ve Toplum, 1, 39-68.

GÖKSEL, A., Aydıntan, B., ve Bingöl, D. (2010). Örgütlerde Bilgi Paylaşım Davranış1: Sosyal Sermaye Boyutundan Bir Bakış. Ankara Üniversitesi SBF Dergisi, 65(4), 88-109.

HOFSTEDE, G., Hofstede, G. J., ve Minkov, M. (2010). Cultures and Organizations: Software of the Mind. McGraw-Hill.

KAPU, H. (2008). Sosyal Sermaye ve Organizasyonların Öngörü Yeteneğini Geliştirme Gücü. Atatürk Üniversitesi İktisadi ve İdari Bilimler Dergisi, 22(1), 259-288.

KARAGÜL, M. (2012). Sosyal Sermeye (Kapitalizmin Kör Noktast). Ankara: Nobel Yayın.

KARAGÜL, M., ve Dündar, S. (2006). Sosyal Sermaye ve Belirleyicileri Üzerine Ampirik Bir Çalışma. Akdeniz Üniversitesi İktisadi ve İdari Bilimler Fakültesi Dergisi, 6(12), 61-78.

KARAGÜL, M., ve Masca, M. (2005). Sosyal Sermaye Üzerine Bir İnceleme. Ekonomik ve Sosyal Araştırmalar Dergisi, 1, 37-52.

KIREL, Ç., Topgül, S., ve Altınok, A. (2016). Bankacılık Sektöründe Sosyal Sermaye, Motivasyon ve Performans Yönetimi Arasındaki İlişkinin Analizi. "İŞ, GÜÇ" Endüstri İişkileri ve İnsan Kaynakları Dergisi, 18(2), 17-40.

KİTAPÇI, İ. (2015). Motivasyonel Bir Güç Olarak Sosyal Sermaye Kavramı ve Rasyonalitesi. Hukuk ve İktisat Araştırmaları Dergisi, 7(1-2), 11-36.

LIN, N. (1999). Building a Network Theory of Social Capital. Connections 22, 22(1), 2851.

ONYX, J., ve Bullen, P. (2000). Measuring Social Capital. The Journal of Applied Behavioral Science, 36(1), 23-42.

ÖZDEMİR, A. A. (2008). Sosyal Ağ Özellikleri Bakış Açısıyla Sosyal Sermaye ve Bilgi Yaratma İlişkisi: Akademisyenler Üzerinde Yapılan Bir Alan Araştırmas1. Anadolu Üniversitesi Sosyal Bilimler Dergisi, 8(2), 81-102. 
ÖZDEMIR, A. A. (2008a). Çalışanların İș Tatminlerinin Arttıılmasında Örgütsel Sosyal Sermaye Yeni Bir Belirleyici Olabilir mi? Yönetim Bilimleri Dergisi, 6(1).

ÖZEN, Ş., ve Aslan, Z. (2006). İçsel ve Dışsal Sosyal Sermaye Yaklaşımları Açısından Türk Toplumunun Sosyal Sermaye Potansiyeli: Ortadoğu Sanayi ve Ticaret Merkezi (Ostim) Örneği. Akdeniz Üniversitesi İktisadi ve İdari Bilimler Fakültesi Dergisi, 6(12), 130-161.

PAŞAMEHMETOĞLU, A. (2010). Kültürel Değerlerde Farklılaşmanın Sosyal Sermayeye Etkileri: Ankara Mobilyacılar Sitesi (Siteler) ve Ortadoğu Sanayi ve Ticaret Merkezi (Ostim) Üzerine Bir Araştırma. Başkent Üniversitesi Sosyal Bilimler Enstitüsü,Doktora Tezi.

PUTNAM, R. D. (2000). Bowling Alone: The Collapse and Revival of American Community. NewYork: Simon and Schuster.

SARGUT, A. S. (2006). Sosyal Sermaye: Yapının Sunduğu Bir Olanak mı, Yoksa Bireyin Amaçlı Eylemi mi? Akdeniz Üniversitesi İ.̇.B.F. Dergisi, 12, 1-13.

SEÇER, B. (2009). İşgücü Piyasasında Sosyal Sermaye. Kamu-iş, 10(3), 103-130.

STIMSON, R., John Western, S. B., ve Gellecum, Y. V. (2003). Measuring Community Strength and Social Capital . ERSA 2003 Congress (s. 1-38). Jyväskylä, Finland: The European Regional Science Association.

TAŞTAN B., S. (2015). Örgütsel Güven ve Sosyal Adalet Algısının Örgütlerde Sosyal Sermaye Yapısı ile İlişkilerinin İncelenmesi. Eskişehir Osmangazi Üniversitesi Sosyal Bilimler Dergisi, 16(2), 13-58.

TUNCAY, N. (2016). Yöneticilerin Liderlik Davranışlarının Sosyal Sermaye Üzerindeki Etkisi: Konya İşletmelerinde Bir Uygulama. Konya: KTO Karatay Üniversitesi Sosyal Bilimler Enstitüsü, Yüksek Lisans Tezi.

TUNÇAY, S. S., Özer, P. S., ve Tozkoparan, G. (2015). Yerel Yazında Sosyal Sermaye Araştırmaları: Odaklar ve Boşlukların İncelenmesi. İşletme Fakültesi Dergisi, 16(2), 71-89.

TURAN, A. (2013). Sosyal Sermayenin Bilgi Paylaşma Tutumuna Etkisi: Motivasyonun Bu Etkideki Rolü Üzerine Bir Araştırma. İstanbul: İstanbul Üniversitesi Sosyal Bilimler Enstitüsü,Doktora Tezi.

TURGUT, E., ve Begenirbaş, M. (2013). Çalışanların Yenilikçi Davranışları Üzerinde Sosyal Sermaye ve Yenilikçi İklimin Rolü: Sağlık Sektöründe Bir Araştırm. KHO Bilim Dergisi, 23(2), 101-124.

YILDIZ, T., Aykanat, Z., ve Tüzemen, S. (2016). Etik Liderliğin Sosyal Sermaye Üzerindeki Etkisi. Dokuz Eylül Üniversitesi İktisadi ve İdari Bilimler Fakültesi Dergisi, 31(2), 229-250. 